\title{
Defining Report
}

\section{Identification of the Adult Human Hemangioblast}

\author{
SONJA LOGES, ${ }^{1}$ BORIS FEHSE, ${ }^{1}$ MARC A. BROCKMANN, ${ }^{2}$ KATRIN LAMSZUS, ${ }^{2}$ \\ MARTIN BUTZAL, ${ }^{1}$ MARKUS GUCKENBIEHL, ${ }^{1}$ GUNTER SCHUCH, ${ }^{1}$ \\ SÜLEYMAN ERGÜN, ${ }^{3}$ UTA FISCHER, ${ }^{1}$ AXEL R. ZANDER, ${ }^{1}$ DIETER K. HOSSFELD, ${ }^{1}$ \\ WALTER FIEDLER, ${ }^{1,4}$ and URSULA M. GEHLING ${ }^{1,4}$
}

\begin{abstract}
Recent studies show that human $\mathrm{CD} \mathrm{133}^{+}$(previously known as $\mathrm{AC}^{+33}{ }^{+}$) cells from mobilized peripheral blood consist of stem cells with either hematopoietic or endothelial potential. To test whether this population also contains individual precursors with both capacities, the defining characteristics of the elusive adult hemangioblast, we developed a culture system that allows single-cell analyses of differentiation. In the presence of vascular endothelial growth factor (VEGF), stem cell growth factor (SCGF), and FLT-3 ligand, CD133 ${ }^{+}$-enriched cells were first expanded and the amplified cells were transduced with a vector encoding an enhanced green fluorescent protein (EGFP) marker gene. Single EGFP ${ }^{+}$cells were then cocultured with corresponding nontransduced cells from the same experiment, yielding 50-100 marked cells in 8\% of the wells after 2 weeks. The resultant cells were divided and differentiated with either granulocyte colony-stimulating factor (G-CSF) or with SCGF and VEGF. These culture conditions resulted in the formation of neutrophil or endothelial cells, respectively, as identified morphologically and by phenotypic staining. Dual differentiation of EGFP $^{+}$cells could be observed in one-quarter of clones from single-seeded cells, suggesting that $2 \%$ of EGFP $^{+}$cells were in fact human hemangioblasts. These cells could be expanded for at least 28 days without losing this dual capacity. Hence, this culture system may be of clinical relevance in the development of cellular therapies for disorders involving hematopoiesis and the vascular system. In addition, our results provide important information related to the development of the vasculature and the potential role of hemangioblasts in vasculogenesis in adult humans.
\end{abstract}

\section{INTRODUCTION}

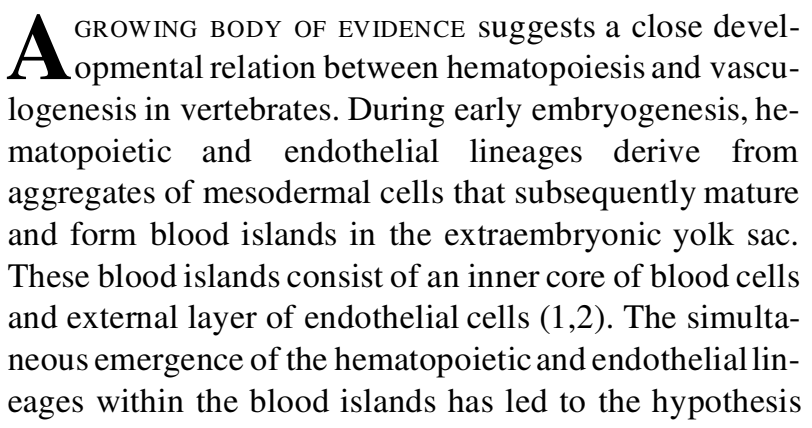

that they originate from a common precursor referred to as the hemangioblast (2). The concept of a common ancestral cell has been supported by the observation that the two lineages possess several phenotypic and molecular similarities (3-8). In addition, gene targeting experiments have shown that mutations of single mouse or zebrafish genes result in defective development of both lineages (9-13). Studies on zebrafish embryos demonstrating that ectopic expression of the transcription factor SCL in early mesoderm results in an overproduction of hemangioblasts provide further evidence for its existence (14). Recently, the in vitro equivalent of the hemangioblast has been iden-

${ }^{1}$ Department of Medicine, ${ }^{2}$ Department of Neurosurgery, and ${ }^{3}$ Department of Anatomy, University Hospital Eppendorf, Hamburg, Germany.

${ }^{4}$ W.F. and U.M.G. contributed equally to this work. 
tified (15-17) and characterized as a transient cell during embryonic development (16).

The emergence of the blood islands in the yolk sac marks the onset of vascularization in the developing embryo. Two different processes contribute to the formation of the vascular system. The first process, vasculogenesis, requires the differentiation of endothelial cells from hemangioblasts and their subsequent organization into a primary capillary plexus $(18,19)$. The second process, angiogenesis, results in the formation of new vessels by sprouting from preexisting blood vessels $(20,21)$. Primary differentiation of endothelial cells from hemangioblasts or angioblasts has long been considered to be a process that is restricted to early embryogenesis, whereas angiogenesis occurs both during development and postnatal life. However, recent studies indicate that the $\mathrm{CD} 34^{+}$cell population in bone marrow and peripheral blood from adult humans contains endothelial progenitors (22-24). We have shown that a subset of $\mathrm{CD}_{3} 4^{+}$stem and progenitor cells expressing the cell-surface marker CD133 has the capacity to differentiate into endothelial cells (25). In addition, Peichev et al. (26) reported that circulating $\mathrm{CD}^{+} 4^{+}$cells coexpressing CD133 and the vascular endothelial growth factor receptor-2 (VEGFR-2, also known as flk-1/KDR) comprise a functional population of endothelial progenitors. Animal studies suggest that human endothelial progenitors contribute to neovascularization in vivo (27-30). Furthermore, a report by Gunsilius et al. (31) provides strong evidence for the existence of hemangioblasts in adult humans. By culturing bone marrow stem cells from patients with chronic myelogenous leukemia (CML), the investigators demonstrated that both hematopoietic and endothelial cells express the pathogonomic BCR/ABL fusion gene, the mutation that is restricted to the subset of CML stem cells.

In a series of elegant experiments, Choi's group showed that the embryonic hemangioblast is defined by the expression of VEGF-2 and SCL $(16,32,33)$. Such a definition does not yet exist for the adult hemangioblast. A first study that addressed this question suggests that in the murine system, the adult hemangioblast may display a hematopoietic phenotype (34). Pelosi et al. claimed that in humans, the postnatal hemangioblast is characterized by the expression of CD34 and VEGFR-2 (35). However, no additional information on the expression patterns (e.g., CD133, CD45) of these cells was provided.

In this study, we evaluated the hemangioblastic potential of $\mathrm{CD}_{133^{+}}$cells from mobilized peripheral blood. We show that individual CD133+ cells have the capacity to generate both hematopoietic and endothelial cells and that these bipotent precursor cells exhibit a hematopoietic phenotype. This finding has been supported by two recent studies showing that a subset of hematopoietic stem cells can serve as hemangioblasts (see Note Added in Proof, p. 240).

\section{MATERIALS AND METHODS}

\section{Input cells}

Cells were isolated from frozen leukapheresis products of 9 patients undergoing high-dose chemotherapy (HDC) with autologous hematopoietic progenitor cell (HPC) support. Peripheral blood (PB) progenitor cells were collected by leukapheresis after mobilization of HPC with recombinant human granulocyte colony-stimulating factor (G-CSF), administered subcutaneously (s.c.) at 5 $\mu \mathrm{g} / \mathrm{kg} / \mathrm{day}$ for up to 7 days.

\section{Enrichment of $\mathrm{CD}_{133^{+}}$cells}

After thawing, products were resuspended in phosphate-buffered saline (PBS; Life Technologies, Karlsruhe, Germany) supplemented with $0.5 \%$ human serum albumin (HSA; Blood Donating Service of the German Red Cross, Hamburg, Germany) and 0.6\% ACD-A. Deoxyribonuclease I (DNase I; Sigma, Deisenhofen, Germany) was added at $100 \mathrm{U} / \mathrm{ml}$, and the specimens were shaken gently for $30 \mathrm{~min}$ at room temperature. Mononuclear cells (MNC) were isolated by density gradient centrifugation over Ficoll-Hypaque (Pharmacia, Uppsala, Sweden) for $20 \mathrm{~min}$ at $500 \times g$ and washed two times in PBS at $300 \times g$ to remove platelets. MNCs were then resuspended in PBS, incubated with CD133 monoclonal antibody (mAb)-conjugated paramagnetic microbeads (CD133 Isolation Kit, Miltenyi Biotec, Bergisch-Gladbach, Germany), washed, and then loaded on an automatic magnetic separation column device (AutoMACS, Miltenyi Biotec). CD133 ${ }^{+}$cells were isolated using the software program Posseldx (Miltenyi Biotech). For all preparative steps, as well as for the separation procedure, PBS was supplemented with $0.5 \%$ HSA and $0.6 \%$ ACDA. The purity and phenotype of the $\mathrm{CD} 133^{+}$cells was determined by flow cytometry.

\section{Cultures of human $\mathrm{CD} 133^{+}$cells}

Freshly isolated $\mathrm{CD} 133^{+}$cells were cultured in fibronectin-coated 24-well plates (fibronectin from Life Technologies, plates from Greiner, Hamburg, Germany) at a density of $2 \times 10^{6}$ cells $/ \mathrm{ml}$ in Iscove's modified Dulbecco medium (IMDM) supplemented with $10 \%$ fetal bovine serum (FBS; Sigma), 10\% horse serum (Sigma), and $10^{-6} \mathrm{M}$ hydrocortisone (Sigma). In pilot studies, various growth factor combinations were compared for their ability to induce proliferation, including vascular endothelial growth factor (VEGF; $50 \mathrm{ng} / \mathrm{ml}$ ), basic fibroblast growth factor (bFGF; $10 \mathrm{ng} / \mathrm{ml}$ ), hepatocyte growth factor (HGF; $10 \mathrm{ng} / \mathrm{ml}$ ), stem cell growth factor (SCGF; 100 $\mathrm{ng} / \mathrm{ml}$ ), stem cell factor (SCF; $100 \mathrm{ng} / \mathrm{ml}$ ), FLT-3 ligand $(50 \mathrm{ng} / \mathrm{ml})$, epidermal growth factor (EGF; $10 \mathrm{ng} / \mathrm{ml})$, in- 
sulin-like growth factor-1 (IGF-1; $10 \mathrm{ng} / \mathrm{ml}$ ), and leukemia-inhibiting factor (LIF; $1 \mathrm{ng} / \mathrm{ml}$ ), respectively. All cytokines were from TEBU (Frankfurt, Germany). The combination of VEGF, SCGF, and FLT-3 ligand was determined to increase cell proliferation significantly and was then used for the expansion of the $\mathrm{CD} 133^{+}$cells.

Following 4 days in culture under these conditions, $30 \%$ of the cells were retrovirally transduced for 2 consecutive days, as described below. At day 6 of culture, transduced cells as well as non-transduced cells were harvested by gentle pipetting. Non-transduced cells were replated at $2 \times 10^{6}$ cells $/ \mathrm{ml}$ in opaque microtiter well-plates under the same culture conditions. To study the developmental potential of individual $\mathrm{CD} 133^{+}$cells, single transduced cells were transferred to cultures with corresponding non-transduced cells from the same sample by limiting dilution, and expanded at the single-cell level for at least six cell doublings. The cultures were incubated at $37^{\circ} \mathrm{C}$ in $5 \% \mathrm{CO}_{2}$. Additional feeding was performed, depending on cell proliferation. Then, supernatant was removed by gentle pipetting and replaced with fresh medium.

Following 18-28 days of expansion, cells of each well were harvested separately. For endothelial differentiation, one-half of the cells from an individual well were cultured for 14 days in IMDM with $10 \%$ FBS, $10 \%$ horse serum, $10^{-6} \mathrm{M}$ hydrocortisone, VEGF (50 $\mathrm{ng} / \mathrm{ml}$ ), and SCGF $(100 \mathrm{ng} / \mathrm{ml})$. The remaining half was cultured for 7 days in IMDM with $10 \%$ FBS, $10 \%$ horse serum, $10^{-6}$ $\mathrm{M}$ hydrocortisone, and G-CSF $(1000 \mathrm{U} / \mathrm{ml})$ for hematopoietic differentiation. Cells were then harvested for analysis. In parallel experiments, pure cultures with nontransduced cells were performed and analyzed by immunocytochemistry, flow cytometry, and colony assays and in an animal model.

\section{Producer cell lines}

The replication-deficient retroviral vector SF11@ EGFPrev, a FMEV-based construct encoding the enhanced green fluorescence protein (EGFP) (36), was produced from the PG13 packaging cell line. PG13 cells were kept in Dulbecco's modified Eagle medium (DMEM with glutamax) supplemented with $10 \%$ heatinactivated FBS and $1 \mathrm{mM}$ sodium pyruvate (all from Gibco BRL, Paisley, Scotland). We used X-Vivo 10 (Bio Whittaker, Walkersville, MD) to obtain serum-free vector-containing medium as described (37).

\section{Transduction of $\mathrm{CD}_{133^{+}}$cells}

To preload fibronectin-coated, 24-well tissue plates with the vector-containing supernatant, four to six centrifugation steps $(1000 \times g)$ in a varifuge 3.0 RS (Heraeus Instruments, Hanau, Germany) at $4^{\circ} \mathrm{C}$ for $30 \mathrm{~min}$ were carried out. Supernatant was discarded after each centrifugation step. For transduction, we incubated $\mathrm{CD}_{133^{+}}$cells at a density of $2 \times 10^{6}$ cells $/ \mathrm{ml}$ per well in their expansion medium (as described above) overnight in the preloaded wells without further centrifugation (38). For in vitro studies, two transduction cycles were performed. For in vivo studies, $\mathrm{CD} 133^{+}$cells were transduced for 3-5 consecutive days.

\section{Clonogenic assays for multilineage hematopoietic and endothelial progenitor cells}

Purified $\mathrm{CD}_{133^{+}}$cells as well as nontransduced cells expanded for 48 days were plated at $5 \times 10^{3}$ cells $/ \mathrm{ml}$ in methylcellulose (complete media from Cell Systems, St. Katharinen, Germany) as previously described (25). In brief, cultures were stimulated either with a combination of hematopoietic growth factors including: SCF (50 $\mathrm{ng} / \mathrm{ml}$ ), interleukin-3 (IL-3; $20 \mathrm{ng} / \mathrm{ml})$, IL-6 (20 ng/ml), G-CSF (20 ng/ml), GM-CSF (20 ng/ml), plus erythropoietin $(3 \mathrm{U} / \mathrm{ml}$ ) (all from Cell Systems) or with the combination of SCGF (100 ng/ml) and VEGF (50 ng/ml) (both from TEBU). All cultures were performed in duplicate, incubated at $37^{\circ} \mathrm{C}$ in $5 \% \mathrm{CO}_{2}$ and $95 \%$ humidity, and scored after 14 days of culture using an inverted microscope. The absolute number of all types of hematopoietic colonies and of CFU-EC at day 0 and day 14 of culture was calculated by multiplying the number of colonies $/ 1 \times 10^{3}$ input cells by the total number of cells present in the respective expansion culture.

\section{Culture and preparation of human umbilical vein endothelial cells}

Primary human umbilical vein endothelial cells (HUVEC) were purchased from Clonetics (via Cell Systems, St. Katharinen, Germany) and maintained in EGM-2 (Clonetics). HUVEC were harvested by trysinization, washed in PBS, and spun at $500 \mathrm{rpm}$ for 5 min onto glass slides by cytocentrifugation.

\section{Immunofluorescence staining of expanded and differentiated cells}

Freshly isolated $\mathrm{CD} 133^{+}$cells as well as expanded non-transduced cells were spun onto glass slides as described above. Slides were air-dried for at least $10 \mathrm{~min}$ and immunostained for the expression of the VEGF receptor 2 (VEGFR2/KDR; Sigma), CD31, von Willebrand factor (vWF), VE-Cadherin (all from Pharmingen), and Ulex europaeus agglutinin-1 (Sigma). $\mathrm{EGFP}^{+}$cells cultured for 14 days in expansion medium and for 14 days in differentiation medium were washed twice and spun onto glass slides as described above. After blocking with $10 \%$ FBS/RPMI, cytospins were incubated with the primary antibody for $30 \mathrm{~min}$. The following primary anti- 


\section{LOGES ET AL.}

bodies were used: anti-VE-Cadherin and anti-CD13 (both from Pharmingen, Hamburg, Germany), and Ulex europaeus agglutinin-1. This step was followed by incubation with a Texas Red-conjugated goat-anti-mouse secondary antibody (DAKO, Hamburg) for $30 \mathrm{~min}$. Cells were fixed in methanol for $15 \mathrm{~min}$ at $-20^{\circ} \mathrm{C}$ and counterstained with DAPI (4',6-Diamidino-2-Phenylindole, Boehringer Mannheim, Germany).

A positive control for the staining with anti-KDR mAb, anti-VE-Cadherin $\mathrm{mAb}$, and Ulex europaeus agglutinin1 was performed with HUVEC. As negative controls, peripheral blood smears as well as the specimen itself were used; these were incubated with a mouse anti-human immunoglobulin ( $\operatorname{IgG}$ ) instead of the primary antibody. Stained cells were examined for the presence of positive cells using a Zeiss Axioplan (Jena, Germany) fluorescence microscope.

\section{Flow cytometry}

Isolated $\mathrm{CD} 133^{+}$as well as expanded nontransduced cells were washed twice and prepared for two-color flow cytometry. The following PE-conjugated monoclonal antibodies were used: anti-C133 (Miltenyi Biotec), antiCD14, anti-CD31, (all from Pharmingen), and anti-c-kit (An der Grub, Kaumberg, Austria). The fluorescein isothiocyanate (FITC)-conjugated monoclonal antibodies included: anti-CD34, anti-CD105, anti-CD7, and anti-thy-1 (all from Pharmingen). Isotype-matched mouse Ig served as controls. Cells were incubated with the $\mathrm{mAb}$ for $30 \mathrm{~min}$ at $4^{\circ} \mathrm{C}$. Two-color flow cytometric analysis was performed using a FACS CALIBUR flow cytometer (Becton Dickinson) and Cell Quest software (Becton Dickinson). Each analysis included at least 5000 events. The percentage of $\mathrm{CD}_{133^{+}}$cells present was assessed after correction for the percentage of cells reactive with an isotype control. Using isotype-controls for PE and FITC, gates for phenotypic analysis of $\mathrm{CD}_{133^{+}}$cells were set so that the lower left panel contained at least $98 \%$ of the total cells analyzed.

\section{Animal studies}

After 14 days of culture in expansion medium and an additional 14 days in differentiation medium, CD133 ${ }^{+}$. derived cells were harvested by trypsinization and washed in PBS before injection into mice. Additionally, cultured tumor cells of the lung cancer cell line A549 (a gift from Prof. K. Havemann, Institute of Molecular Biology and Cancer Research, Marburg, Germany) were prepared, as previously described (25). In parallel experiments, SCID mice were injected subcutaneously with either $1 \times 10^{6}$ tumor cells, with $1 \times 10^{6} \mathrm{CD} 133$-derived putative endothelial cells, or with a mixture of $1 \times 10^{6}$ tumor cells and $1 \times 10^{6} \mathrm{CD} 133$-derived cells. All recipients survived the procedure. At week 5 post-transplan- tation, all mice were killed for histochemical analysis of the grown tumors.

\section{Immunohistochemical analysis}

Tissue blocks of tumors grown in severe combined immunodeficient (SCID) mice following subcutaneous injection of either $1 \times 10^{6}$ A549 lung cancer cells or a mixture of $1 \times 10^{6}$ A549 cells plus $1 \times 10^{6} \mathrm{CD} 133$-derived cells were prepared, as previously described (25). In brief, we used the mAb 4D1/C2 against CEACAM1 together with an amplification combination of the peroxidase antiperoxidase and the avidin-biotin-peroxidase complex technique. The peroxidase was visualized by use of the Nickel-glucose technique. The specimens were counterstained with Calcium Red. Controls were performed as described (25).

\section{RESULTS}

\section{Phenotypic analysis of purified $\mathrm{CD} 133^{+}$cells}

Flow cytometry was used to characterize the selected CD133 ${ }^{+}$cells (Table 1 ). The mean purity was $98.3 \% \pm$ 0.3 (range 95.7-99.9\%). Two-color fluorescence analysis revealed a high percentage (mean $97.5 \%$, range 90.6-99.9\%) of cells coexpressing the CD34 antigen. As reported earlier (25), small subsets of $\mathrm{CD} 133^{+} \mathrm{CD} 34^{-}$ cells $(0.3-5.1 \%)$ were present, whereas $\mathrm{CD} 133^{-} \mathrm{CD} 34^{+}$ cells were not detected. Purified $\mathrm{CD} 133^{+}$cells were also stained for CD90 (thy-1), CD117 (c-kit), CD14, CD31 (PECAM-1), and CD105 (endoglin). Virtually all $\mathrm{CD} 33^{+}$cells were $\mathrm{CD} 31^{+}(>99 \%)$. CD $90^{+}$cells ranged from $4.0 \%$ to $42.3 \%$ and $\mathrm{CD} 117^{+}$cells from $1.9 \%$ to $27.2 \%$. Very low percentages of $\mathrm{CD} 133^{+}$cells expressed the monocytic antigen CD14 (1.5\%). To characterize the enriched $\mathrm{CD}_{133^{+}}$populations further, cells were analyzed by immunofluorescence for the presence of KDR and for their ability to bind to Ulex europaeus agglutinin1. The analysis also included the endothelial markers CD31, vWF, and VE-Cadherin. The percentages of positive cells and their staining patterns are shown in Table 2 and Fig. 1 . Less than $1 \%$ of the $\mathrm{CD} 133^{+}$cells expressed the receptor tyrosine kinase KDR. None of the populations assayed stained positively for either Ulex europaeus agglutinin-1 or vWF and VE-Cadherin, respectively. In accordance with the findings from flow cytometric analysis, CD31 was expressed on $>99 \%$ of the purified cells.

\section{Characterization of CD133-derived cells in expansion culture}

Enriched $\mathrm{CD}_{133^{+}}$cells were transferred to fibronectin-coated wells and cultured in the presence of FLT- 
day 0
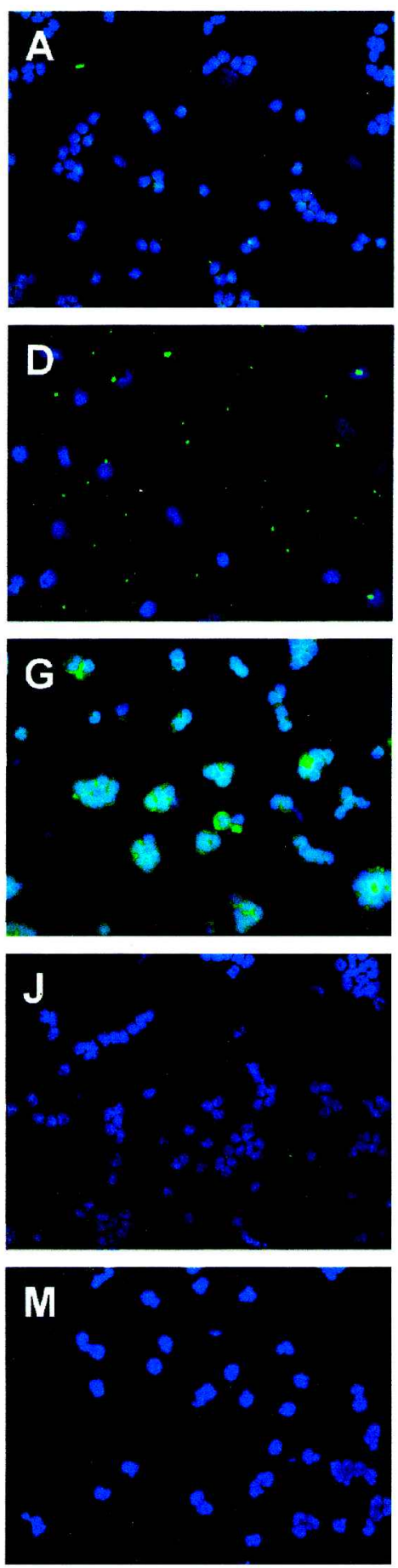

\section{$1+\cdots 14$ expanded}
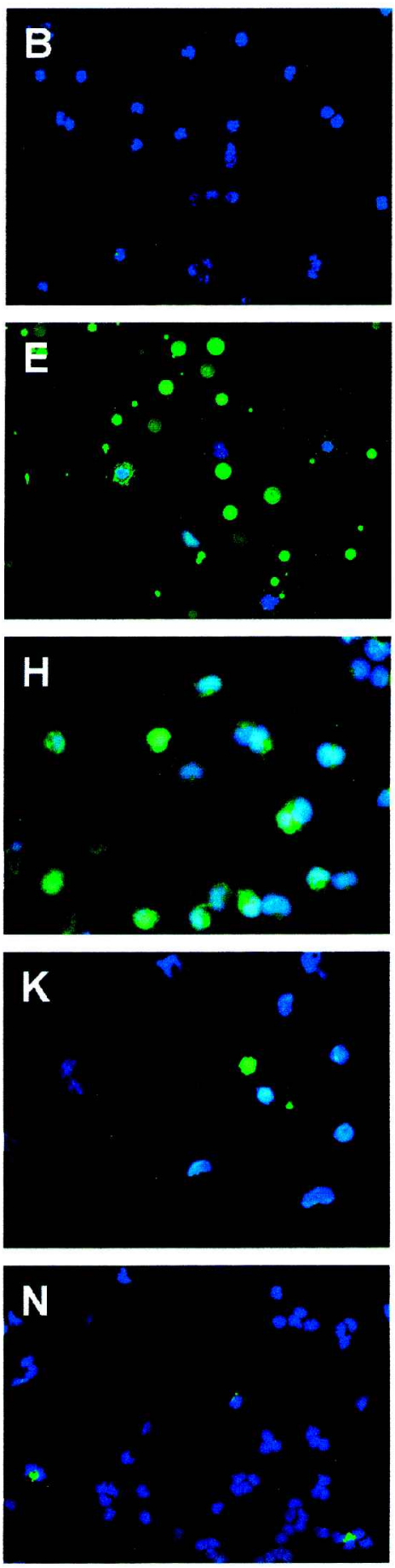

\section{day 14 differentiated}
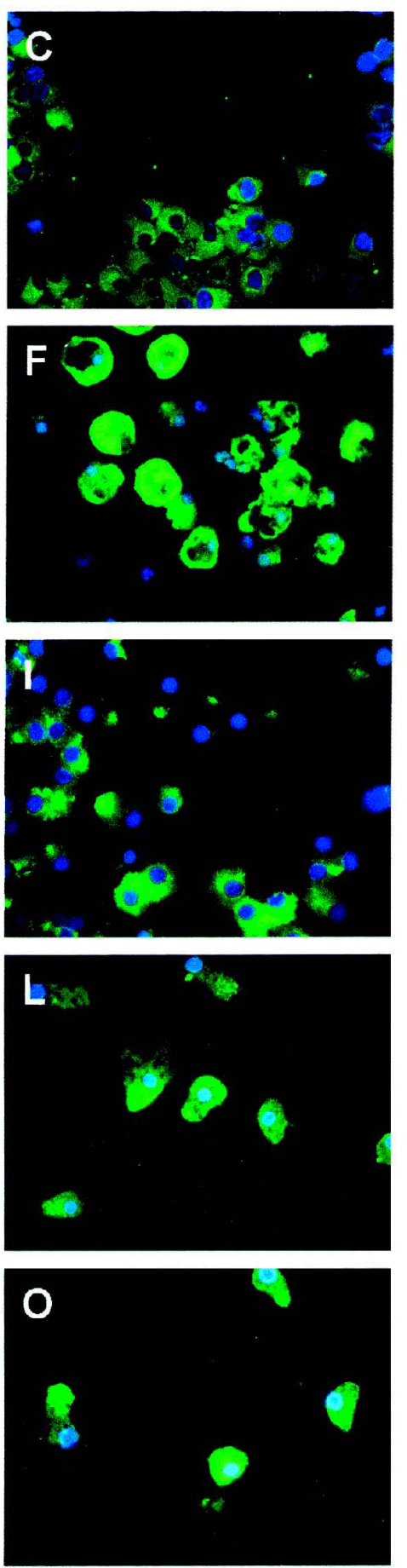

FIG. 1. Immunofluorescence analysis of freshly isolated $\mathrm{CD} 133^{+}$cells, $\mathrm{CD} 133$-derived cells expanded for 14 days, and expanded cells cultured for 14 days in the presence of SCGF and VEGF. (A, D, G, J, and M) Freshly enriched CD133 ${ }^{+}$cells labeled with anti-VE-cadherin monoclonal antibody (MoAb), anti-KDR MoAb, anti-CD31 MoAb, anti-vWF MoAb, and Ulex europaeus agglutinin-1, respectively. (B, E, H, K, and $\mathbf{N}$ ) Staining patterns of CD133-derived cells expanded for 14 days using the same MoAbs. (C, F, I, L, O) Expanded CD133-derived cells cultured for 14 days with SCGF and VEGF stained in the same manner. 
LOGES ET AL.

Table 1. Phenotype of Freshly Isolated CD133+ Cells (Day 0) and CD133-Derived Cells during Expansion Culture with SCGF, VEGF, and FlT-3 Ligand

\begin{tabular}{|c|c|c|c|c|c|c|c|c|c|c|c|}
\hline \multirow[b]{2}{*}{$M o A b$} & \multicolumn{11}{|c|}{ Days of culture } \\
\hline & 0 & 3 & 6 & 9 & 12 & 14 & 24 & 29 & 35 & 41 & 48 \\
\hline CD133 & $98.3 \pm 0.5$ & $81.1 \pm 4.1$ & $58.6 \pm 20.9$ & $37.6 \pm 26.9$ & $8.1 \pm 1.5$ & $25.2 \pm 7.7$ & 4.48 & 33.5 & 61.1 & 30.3 & 56.5 \\
\hline CD34 & $97.8 \pm 0.6$ & $91.1 \pm 2.5$ & $37.2 \pm 5.2$ & $11.5 \pm 5.2$ & $4.4 \pm 1.9$ & $5.5 \pm 1.1$ & 1.0 & 3.1 & 6.0 & 5.7 & 3.5 \\
\hline CD90 & $15.2 \pm 3.8$ & $25.3 \pm 24.4$ & $2.29 \pm 1.0$ & $32.7 \pm 22.2$ & $24.4 \pm 16.1$ & $24.5 \pm 9.7$ & 19.3 & 32.8 & 26.5 & 31.3 & 60.1 \\
\hline CD117 & $8.2 \pm 3.0$ & $24.8 \pm 8.1$ & $43.5 \pm 13.9$ & $15.0 \pm 7.7$ & $2.2 \pm 0.7$ & $7.7 \pm 2.5$ & 3.4 & 5.2 & 15.0 & 7.1 & 14.3 \\
\hline CD14 & $1.5 \pm 0.6$ & $2.1 \pm 1.2$ & $31.6 \pm 9.9$ & $48.9 \pm 4.6$ & $40.2 \pm 4.4$ & $48.3 \pm 6.1$ & 46.3 & 39.1 & 28.2 & 30.6 & 35.0 \\
\hline CD33 & $87.1 \pm 6.7$ & $83.9 \pm 9.5$ & $97.3 \pm 1.9$ & $98.4 \pm 0.7$ & $97.6 \pm 1.1$ & $98.3 \pm 0.7$ & 99.4 & 99.5 & 94.5 & 92.6 & 94.2 \\
\hline CD31 & $99.4 \pm 0.2$ & $99.1 \pm 0.8$ & $99.1 \pm 0.7$ & $98.0 \pm 0.7$ & $97.1 \pm 1.9$ & $98.8 \pm 0.5$ & 99.6 & 99.4 & 99.5 & 99.7 & 94.6 \\
\hline CD105 & $4.2 \pm 1.8$ & $8.7 \pm 6.9$ & $39.9 \pm 22.5$ & $21.5 \pm 15.9$ & $36.2 \pm 31.1$ & $44.0 \pm 16.9$ & 62.0 & 82.9 & 61.4 & 27.3 & 88.8 \\
\hline
\end{tabular}

Data show analysis by flow cytometry from 9 (day 0), 3 (day 0 to day 14), and 1 (day 0 to day 48) experiments. Values are mean \pm SEM.

3 ligand, SCGF, and VEGF. Using these conditions, no significant changes in the morphology of the expanding cells could be observed throughout the culture period. $\mathrm{CD}_{133^{+}}$cells produced a homogeneous loosely adherent population of round cells. Visible proliferation occurred on day 3 of culture. The cell-doubling time varied between 72 and $144 \mathrm{~h}$ for the first doubling and was 48-72 $\mathrm{h}$ for the following six to eight cell doublings. Thereafter, proliferation seemed to be attenuated. As shown in Fig. 2, proliferation curves showed an up to 72.6-fold increase (mean 37.8-fold) in the total cell number after 14 days, and up to 1087 -fold (mean 477 -fold) after 31 days of expansion culture. Flow cytometric studies revealed unexpected phenotypic changes of the cells during expansion culture (Table 1). Following a marked decrease in the percentages of cells expressing the CD133 antigen between day 0 and day 12 of culture, this subset again rose within the next two days. On day 48, more than $50 \%$ of the cells still expressed CD133. In contrast, the proportion of $\mathrm{CD} 34^{+}$cells continuously declined without any significant increase at later timepoints. Although the percentages of $\mathrm{CD} 133^{+}$cells and $\mathrm{CD} 34^{+}$cells dropped significantly between day 0 and day 6 , the sub- set of cells expressing the SCF receptor c-kit showed a five-fold increase within this period of time. In addition, the $\mathrm{CD} 90^{+}$cell fraction expanded two-fold between day 0 and day 9, and remained on this level until day 41 . Analysis on day 48 revealed a further increase of this fraction, so that $60 \%$ of the cells expressed CD90.

A similar development was observed for the CD105 ${ }^{+}$ subset that represented $4.25 \%$ of the cells on day 0 and increased up to $88.8 \%$ on day 48 . The fraction of cells expressing CD14 rose approximately 40-fold until day 9 (mean 48.9\%) and subsequently remained on this level. As mentioned before, the vast majority of freshly enriched $\mathrm{CD} 133^{+}$cells expressed CD31 prior to culture. This phenotypic characteristic was not altered during the expansion period.

Expanding cells were also stained by immunofluorescence on days $3,6,9,12$, and 14 of culture, respectively, for the presence of KDR (Table 2). Until day 9, only few $(<1 \%) \mathrm{KDR}^{+}$cells were detectable (data not shown). This was consistently demonstrated in three independent experiments. On day $12, \mathrm{KDR}^{+}$cells ranged from less than $1 \%$ to $6.4 \%$, followed by a further increase of $\mathrm{KDR}^{+}$ cells on day $14(4.7-24.0 \%)$. None of the cells expanded

Table 2. Immunofluorescence Staining of CD133 ${ }^{+}$Cells at Different Developmental Stages

\begin{tabular}{lccccc}
\hline & \multicolumn{5}{c}{ Antibodies } \\
\cline { 2 - 5 } Cells & CD31 & $v W F$ & CD144 & Ulex & KDR \\
\hline Day 0 & $>99$ & 0 & 0 & 0 & $<1$ \\
Day 6, expanded & N.D. & N.D. & N.D. & N.D. & $<1$ \\
Day 14, expanded & $>99$ & $5.3 \pm 1.1$ & 0 & 0 & $11.3 \pm 6.4$ \\
Day 3, differentiated & N.D. & N.D. & N.D. & N.D. & $50.5 \pm 13.5$ \\
Day 9, differentiated & N.D. & N.D. & N.D. & N.D. & $82.5 \pm 1.5$ \\
Day 14, differentiated & $>99$ & $>99$ & $>99$ & $>99$ & $87.0 \pm 3.4$ \\
\hline
\end{tabular}

Abbreviation: N.D., Not done. 
for 14 days stained positively for the endothelial markers VE-Cadherin or Ulex europaeus agglutinin-1 (Fig. 1 and Table 2).

Taken together, these findings suggest that the expanded population maintained stem cell characteristics with positivity for CD133, CD90, CD117, and KDR, but did not contain mature endothelial cells. In addition to phenotypic analysis, expanding cells were studied for their clonogenic potential. The total number of colonies obtained from cells that were expanded for 14 days (d14 cells) is shown in Fig. 3. In comparison to freshly isolated $\mathrm{CD}_{133^{+}}$cells (d0 cells), d14 cells produced significantly higher numbers of all types of hematopoietic colonies and of CFU-EC due to massive increase in total cell numbers. The increments in the total number of colonies were 3-, 76-, 19-, 43-, and 125-fold for BFU-E, CFU-E, CFU-GEMM, CFU-GM, and CFU-EC, respectively. The relative number of colonies (the number of colonies per $5 \times 10^{3}$ input cells) generated from d 14 cells was lower than the number obtained from $\mathrm{d} 0$ cells for CFU-GEMM and CFU-GM, which decreased on average 17-fold and 4.5-fold, respectively. The relative number of BFU-E and CFU-E derived from d14 cells showed a high variation. In four of eight experiments, d14 cells produced numbers of BFU-E and CFU-E that were com- parable to those derived from $\mathrm{d} 0$ cells, whereas in the other half of experiments d14 cells did not generate any BFU-E or CFU-E. In contrast, the relative number of CFU-EC derived from $\mathrm{d} 14$ cells showed on average a two-fold increase as compared to the number of CFU-EC obtained from $\mathrm{d} 0$ cells. This could be demonstrated in all experiments performed. Interestingly, analysis after 40 days of culture demonstrated that the expanded cells still had the capacity to form colonies of the granulocytic/ monocytic lineage (data not shown). The absolute number of GFU-GM generated at this timepoint was comparable to the number of CFU-GM produced from day 0 cells (data not shown).

\section{Transduction of expanded CD133-derived cells}

During expansion culture, one-third of the CD133-derived cells were retrovirally transduced with the enhanced (E) GFP marker gene. Mean transduction efficiency was $30 \%$ (range 9.7-37.9\%; Table 3) after two cycles. For in vivo studies, three additional transduction cycles were performed which increased the mean transduction rate to $59.6 \%$ (range $34.9-73.4 \%$ ). In comparison to nontransduced cells, transduction did not alter morphology and growth pattern of expanding cells.

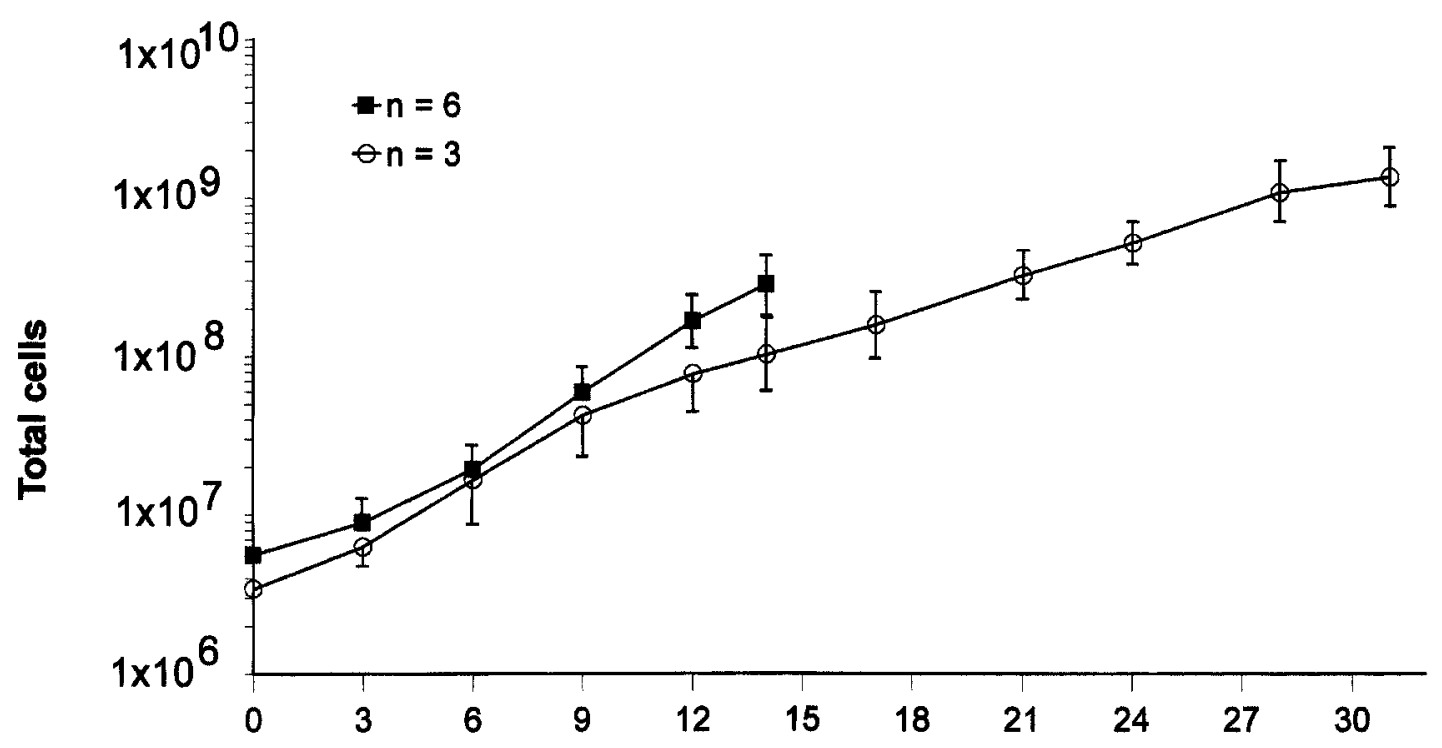

\section{Days}

FIG. 2. Proliferation curves of CD133-derived cells in expansion cultures with SCGF, VEGF, and FLT-3 ligand. Expanded cultures were obtained with the supernatant and the number of cells per milliliter was counted. Proliferation rates of six independent experiments followed up to 14 days, and growth curves of three of these six experiments measured until day 31 of expansion culture are shown. Evaluation of the cell count was performed at various timepoints, depending on the individual growth pattern in each experiment. $n=6$, results from six independent experiments; $n=3$, results from three independent experiments. 


\section{LOGES ET AL.}

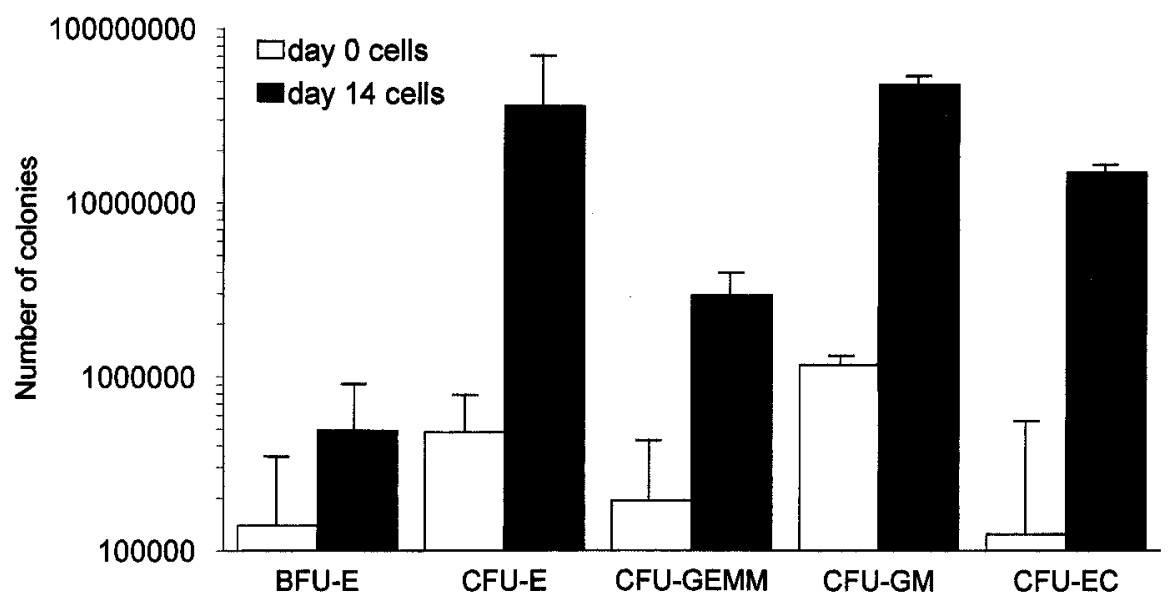

FIG. 3. Clonogenic potential of freshly isolated $\mathrm{CD} 133^{+}$cells (day 0 cells) and CD133-derived proliferating cells expanded for 14 days (day 14 cells) in liquid culture with SCGF, VEGF, and FLT-3 ligand. Each experiment was performed in duplicate. The absolute number of all types of hematopoietic colonies and of CFU-EC generated from freshly isolated CD133 ${ }^{+}$cells and from CD133-derived cells expanded for 14 days was calculated by multiplying the number of colonies $/ 1 \times 10^{3}$ input cells by the total number of cells present in the respective expansion culture. Day 0 cells, freshly isolated $\mathrm{CD}_{133^{+}}$progenitor cells; day 14 cells, CD133-derived cells cultured for 14 days in liquid culture; BFU-E, burst-forming unit erythrocyte; CFU-E, colony-forming unit erythrocyte; CFU-GEMM, colony-forming unit granulocyte-erythrocyte-macrophage-megakaryocyte; CFU-GM, colonyforming unit granulocyte-macrophage; CFU-EC, colony-forming unit endothelial cell (putative endothelial colonies).

\section{Cytokine-dependent differentiation of $C D 133^{+}$ cells expanded at the single-cell level}

To study differentiation of $\mathrm{CD} 133^{+}$cells at the singlecell level, individual $\mathrm{EGFP}^{+}$cells were plated by means of limiting dilution into wells containing $2 \times 10^{6}$ nontransduced cells $/ \mathrm{ml}$ to achieve a sufficient cell density for the growth of the marked cells. Using fluorescence microscopy, wells with single $\mathrm{EGFP}^{+}$cells were identified. After 18-28 days (median 26 days) of expansion culture, on average $8 \%$ (range $4-25 \%$ ) of these wells showed at least six cell doublings of the marked cells. Expanded cells from each well were then split and replated. One half was transferred to liquid cultures supplemented with SCGF and VEGF to induce endothelial differentiation. The remaining half of the cells was placed in medium containing the hematopoietic growth factor G-CSF. In response to SCGF and VEGF, CD133-derived cells became adherent and began to flatten within 1-2 days of culture. Increasing numbers of cells developed an endothelial morphology during a 14-day culture period (Fig. 4A-D). As revealed by immunocytochemistry, these cells expressed VE-Cadherin and stained positive for Ulex europaeus agglutinin-1, indicating their endothelial nature (Fig. 4B,D). However, no adherent cells were observed in cultures with G-CSF. After 7 days, these cells displayed characteristics of mature granulocytes with a typical lobulation of the nucleus on DAPI staining and expression of CD13 (Fig. 4E,F). Dual differentiation of single-seeded cells was observed in one quarter of $\mathrm{EGFP}^{+}$clones, suggesting that $2 \%$ of the $\mathrm{EGFP}^{+}$cells provided hemangioblast activity.

FIG. 4. Immunofluorescence analysis of CD133-derived cells generated in cultures with single-seeded EGFP ${ }^{+}$cells. (A,C) Morphology of $\mathrm{EGFP}^{+}$cells cocultured with non-transduced cells for 14 days in expansion medium and for additional 14 days with SCGF and VEGF. (B) Identical cells as shown in A stained with Ulex europaeus agglutinin-1. (D) Identical cells as shown in $\mathbf{C}$ labeled with VE-Cadherin. (E) Morphology of $\mathrm{EGFP}^{+}$cells expanded in coculture with non-transduced cells for 14 days and differentiated for an additional 14 days in the presence of G-CSF. (F) Identical cells as shown in $\mathbf{E}$ labeled with anti-CD13 MoAb. Original magnification, $20 \times(\mathbf{A}, \mathbf{B})$, and $100 \times(\mathbf{C}-\mathbf{F})$, respectively.

FIG. 5. Immunohistochemical staining of subcutaneously induced tumors with the human-specific MoAb 4D1/C2. (A) Negative control (tumor tissue of mice injected with A549 lung cancer cells alone). (B) Negative control (tumor tissue of animals that were inoculated with A549 cells plus CD133-derived putative endothelial cells). (C) Negative staining with 4D1/C2 of blood vessels in tumors initiated with A549 cells alone. (D) Positive staining of blood vessels in tumors grown after subcutaneous injection of both A549 cells and CD133-derived putative endothelial cells. 4D1/C2 ${ }^{+}$tumor cells are indicated by arrows. Positively stained blood vessels are indicated by arrowheads. Original magnification, $100 \times$. 

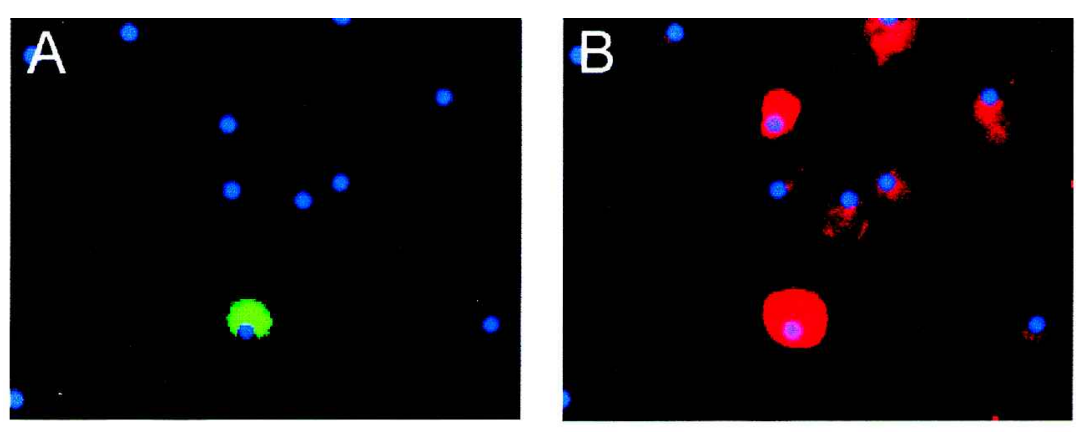

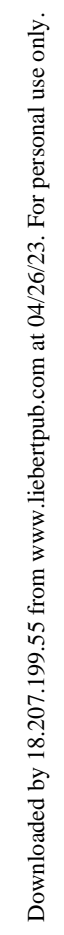
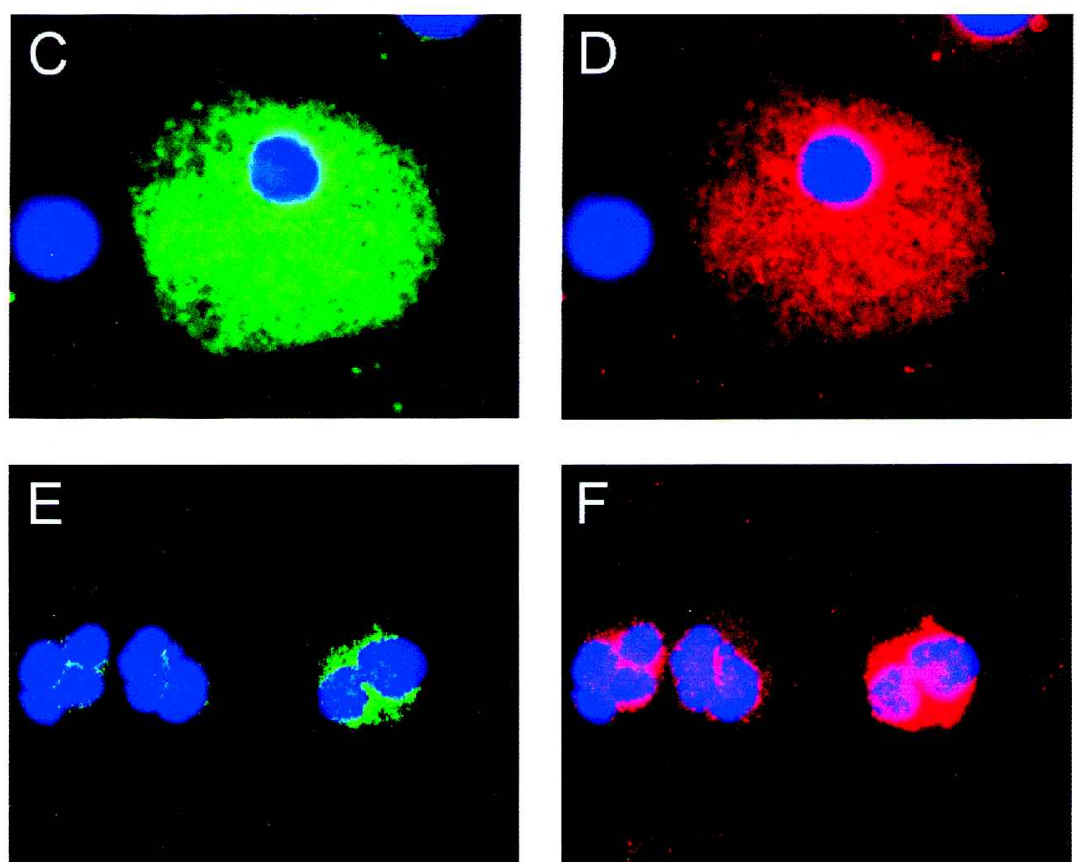

FIG. 4.

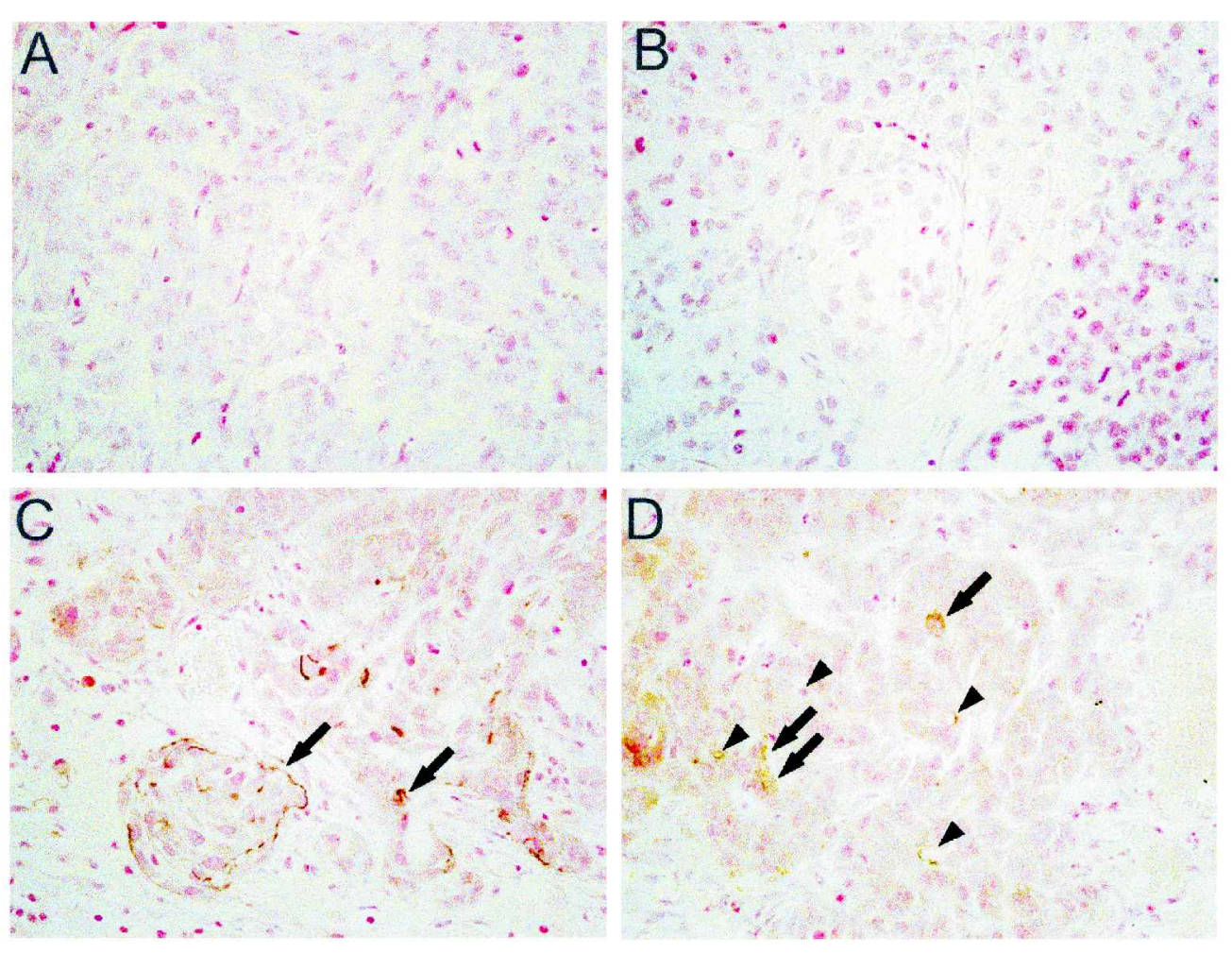


Table 3. Percentages of EGFP $^{+}$CD133-Derived Cells Following Retroviral Transduction

\begin{tabular}{lcc}
\hline & \multicolumn{2}{c}{ Number of transduction cycles } \\
\cline { 2 - 3 } Patient & 2 & 5 \\
\hline 1 & 10.1 & N.D. \\
2 & 22.7 & N.D. \\
3 & N.D. & 34.9 \\
4 & 22.1 & 67.8 \\
5 & 16.4 & 62.3 \\
6 & 18.6 & N.D. \\
7 & 30.8 & N.D. \\
8 & 37.9 & 73.4 \\
9 & 9.7 & N.D. \\
10 & 21.8 & N.D. \\
Mean \pm SEM & $21.1 \pm 6.0$ & 59.6 \pm 10.4 \\
\hline
\end{tabular}

The percentage of $\mathrm{EGFP}^{+}$cells was determined by flow cytometry.

Abbreviation: N.D., Not done.

\section{In vitro and in vivo characterization of CD133- derived endothelial cells}

To further investigate phenotypic changes during differentiation into the endothelial lineage, non-transduced $\mathrm{CD}_{133^{+}}$cells were expanded in bulk cultures for two weeks and then cultured with SCGF and VEGF. Upon withdrawal of FLT-3 ligand, proliferation declined and large adherent cells developed. As early as on day 3 of differentiation culture with SCGF and VEGF, a significant rise of $\mathrm{KDR}^{+}$cells occurred, as detected by immunofluorescence (Table 2). Within the next 10 days, a continuous increase of the $\mathrm{KDR}^{+}$proportion was noted. On day $14,87 \%$ (range $78-91 \%$ ) of the cells stained positive for this marker. Additional staining for VE-Cadherin, Ulex europaeus agglutinin-1, and vWF revealed that virtually all cells expressed these endothelial markers after 14 days of culture, indicating that the vast majority of the cells represented mature endothelial cells.

Xenogenic transplantations were performed to confirm that CD133-derived endothelial cells are functional. SCID mice were injected s.c. with either CD133-derived non-transduced putative endothelial cells, with tumor cells from the lung cancer cell line A549, or with a mixture of CD133-derived cells and tumor cells. Animals that were injected with CD133-derived cells alone did not develop any tumors. Maximal tumor growth was observed in mice that had received both CD133-derived cells and A549 cells. Immunohistochemical analysis of these tumors, using a human specific anti-CEACAM-1 MoAb, revealed positive staining of blood vessels (Fig. 5D), whereas no staining of blood vessel was found in tumors initiated with A549 cells alone (Fig. 5C).

\section{DISCUSSION}

In the present study, we investigated whether the human $\mathrm{CD}_{133^{+}}$population from G-CSF-mobilized blood contains precursors that provide hemangioblast activity. Previous studies have shown that human CD133-expressing cells represent a subset of stem and progenitor cells with hematopoietic capacity (39-41). In addition, we and others have demonstrated that $\mathrm{CD} 133^{+}$cells can differentiate into the endothelial lineage $(25,26)$. The responsible endothelial precursors within the $\mathrm{CD} 133^{+}$population have been identified to coexpress the surface markers CD34 and KDR (26). On the other hand, KDR has been shown to be expressed on human hematopoietic stem cells with multilineage capacity (42). Recently, a study by Pelosi et al. suggested that expression of KDR defines the postnatal hemangioblast (35), as it is the fact in murine embryonic development (15-17). The investigators reported that single $\mathrm{KDR}^{+}$cells could be isolated from mobilized blood by fluorescence-activated cell sorting (FACS) and then cultured in the absence of supplementary cells. However, in the present study less than $0.5 \%$ of the freshly isolated $\mathrm{CD} 133^{+}$cells (purity $>95 \%$ ) were found to express this marker. These results are essentially consistent with a report by Ziegler et al. (42) and Peichev et al. (26). Because the frequency of

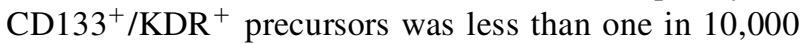
of the unselected cell population, we focussed on the total CD133 ${ }^{+}$cells. In our previous experiments, CD133 ${ }^{+}$ cells were cultured with SCGF and VEGF to induce endothelial differentiation. Proliferation and survival of the cultured cells under these conditions required high initial cell densities, so that cultures with single $\mathrm{CD} 133^{+}$cells could not be performed. To circumvent this problem, we transduced the cells with the EGFP gene and cocultured single marked with non-transduced cells. Using this approach, we demonstrate that cells originating from single $\mathrm{CD} 133^{+}$precursors had the capacity to generate both hematopoietic and endothelial cells. Single cells were expanded on average for 24 days before they were transferred to the differentiation cultures. At that time, a significant proportion of the cells was found to express $\mathrm{KDR}$, as determined by analysis of corresponding nontransduced cells. After 2 weeks of culture, portions of these cells could be differentiated into granulocytes and endothelial cells, depending on the culture conditions. These findings support the concept of a bipotent precursor within the $\mathrm{CD} 133^{+}$population.

In addition to the $\mathrm{KDR}^{+}$cell fraction, another subset of precursors with hematopoietic and endothelial potential may exist within the $\mathrm{CD} 133^{+}$population. Freshly isolated $\mathrm{CD} 133^{+}$cells coexpressed several surface markers that are common to both hematopoietic and endothelial cells, such as CD31, and CD105 $(6,43,44)$. More recently, it has been reported that during differentiation of murine 
embryonic stem cells CD105 is coexpressed on a subset of mesodermal precursors expressing the VEGFR-2 (45). The investigators suggested that the expression of CD105 characterizes the hematopoietic commitment within the Flk- $1^{+}$populations. Nevertheless, the authors speculated that the subset $\mathrm{Flk}-1^{+} / \mathrm{CD} 105^{+}$precursors also includes hemangioblasts. In the human system, Pierelli et al. (44) showed that subsets of circulating $\mathrm{CD} 34^{+}$cells expressing CD105 are enriched in primitive hematopoietic precursors. In bone marrow and cord blood, this subset contained all $\mathrm{CD} 34^{+} / \mathrm{CD} 38^{-}$precursors that are suggested to represent immature stem cells with hematopoietic potential $(46,47)$. Whether human $\mathrm{CD} 34^{+} / \mathrm{CD} 38^{-} / \mathrm{CD} 105^{+}$cells can give rise to cells of the endothelial lineage is unknown.

In addition, expression of CD90 was previously supposed to be restricted to primitive hematopoietic cells $(48,49)$. Recently, it has been reported that CD90 is also expressed on adult vascular endothelium in mice $(50,51)$. We have found more than $20 \% \mathrm{CD} 90^{+}$cells within the expanded population throughout the culture period. One possible explanation for this finding is that the culture conditions used were optimal to support the growth of primitive hematopoietic precursors. Alternatively, expression of CD90 could be a marker for hemangioblasts.

Furthermore, we observed up to $54 \%$ of $\mathrm{CD} 14^{+}$cells after 14 days of culture. CD14 that has been widely accepted as a marker specific for monocytes (52). Two recent studies have revealed expression of CD14 on human endothelial cells $(53,54)$. Moreover, it has been suggested that mature monocytes can transdifferentiate into endothelial cells (55-58). Hence, we cannot exclude that the endothelial cells generated from single $\mathrm{EGFP}^{+}$precursors developed via transdifferentiation of $\mathrm{CD} 14^{+}$cells.

To accomplish efficient transduction of the CD133 ${ }^{+}$ cells, we developed a culture system for the ex vivo expansion of these precursors. Past studies have shown that in the ex vivo expansion systems, proliferation usually occurs with differentiation and loss of stem and progenitor cell activity (59-61). Recently, it has been demonstrated that self-renewal of hematopoietic stem cells can be promoted using a combination of early cytokines, such as FLT-3 ligand, SCF, and thrombopoietin (62). We used the combination of FLT-3 ligand, SCGF, and VEGF, hypothesizing that this cocktail may have the ability to maintain the hematopoietic as well as the endothelial potential of the $\mathrm{CD} 133^{+}$precursors. While stimulation with SCGF and VEGF mainly results in endothelial differentiation of the $\mathrm{CD}_{133^{+}}$population (25), the addition FLT-3 ligand was found to induce high proliferation for an extended culture period. Analysis of the expanded cells revealed several unexpected phenotypic changes. Following a progressive decline from day 0 to day 12 of culture, the proportion of $\mathrm{CD}_{133^{+}}$increased again thereafter. Interestingly, the fraction of cells coexpressing CD34 cells decreased in parallel without any significant increase at later timepoints. Consequently, the culture conditions used supported the growth of $\mathrm{CD} 133^{+} / \mathrm{CD} 34^{-}$cells.

Whether these expanded $\mathrm{CD} 133^{+} / \mathrm{CD} 34^{-}$cells have the primitive stem cell properties as the small subset of $\mathrm{CD} 133^{+} / \mathrm{CD}_{3} 4^{-}$cells that can be found in freshly isolated $\mathrm{CD} 133^{+}$populations (63) remains to be determined. The observation that the proportion of $\mathrm{CD} 0^{+}$cells also increased throughout the culture period leads us to speculate that the expanded $\mathrm{CD} 133^{+} / \mathrm{CD} 34^{-}$population has stem cell activity. In accordance with this interpretation, we could demonstrate that the proportion of precursors with clonogenic potential significantly expanded after 14 days of culture. The increase in the number of colonies was most pronounced for CFU-EC. Together with findings from immunocytochemical analysis, these data suggest that the endothelial colonies derive from $\mathrm{KDR}^{+}$cells that might be selectively expanded in the VEGF-containing culture medium.

Interestingly, after 40 days of culture expanded cells still had the capacity to form hematopoietic colonies, whereas the ability to generate endothelial colonies was lost. On the other hand, our experiments at the singlecell level demonstrated CD133-derived cells could be expanded for up to 28 days without losing the potential to differentiate into both hematopoietic and endothelial cells. Hence, our culture system may be of great clinical relevance in the development of protocols for therapy with ex vivo expanded hematopoietic and endothelial precursors. Furthermore, the presented culture conditions are suitable for an efficient and stable transduction of $\mathrm{CD}_{133^{+}}$stem and progenitor cells, including those with hemangioblastic potential. Transduction did not alter the proliferative or the differentiation potential of the expanded cells. In vivo analysis revealed that the EGFPtransgene was expressed for at least 2 months. The findings from our study may also be useful in the development of novel strategies for gene therapy of genetic, malignant, and vascular diseases.

In conclusion, we identified a subset of $\mathrm{CD} 133^{+}$cells that have the capacity to generate both hematopoietic and endothelial cells and, therefore, fit the description of the hemangioblast. These precursors cells certainly show therapeutic promise, but their physiological relevance is not yet clear. Are these cells involved in maintaining hematopoiesis and vasculogenesis in adults? Work is in progress to address this important issue and to determine if these cells satisfy the stringent criteria defined by Choi and collegues, whose studies have pioneered the definition of the elusive hemangioblast (64).

\section{ACKNOWLEDGMENTS}

This work was supported by grants from the Eppendorfer Krebs- und Leukämie-Foundation, Hamburg, Ger- 
many (U.M.G.), and grants from the Werner-OttoStiftung, Hamburg (S.L.) and the Jung-Stiftung für Wissenschaft und Forschung (M.A.B.). The author would like to thank Drs. P. Kühnl and A. Sputtek for providing leukapheresis products, R. Fillbrandt and D. Ung for excellent technical assistance. We are also grateful to C. Hottendorf for assistance with photography.

\section{Note Added in Proof:}

After this work was accepted for publication, two independent transplantation studies have claimed identification of the postnatal human hemangioblast (Cogley CR et al., Blood 103:133-135, 2004 and Bailey AS et al., Blood 103:13-19, 2004). Both confirm our observations that this bipotent precursor represents a subset of CD34 ${ }^{+}$ bone marrow-derived hematopoietic stem cells with the capacity to contribute to both hematopoietic reconstitution and blood vessel formation.

\section{REFERENCES}

1. Sabin FR. (1920). Studies on the origin of blood vessels and of red corpuscles as seen in the living blastoderm of the chick during the second day of incubation. Contrib Embryol 9:213-262.

2. Murray PDF. (1932). The developmentin vitro of the blood of the early chick embryo. Proc R Soc London 11:497-521.

3. Young PE, S Baumhueter and LA Lasky. (1995). The sialomucin CD34 is expressed on hematopoietic cells and blood vessels during murine development. Blood 85:96-105.

4. Miilauer B, S Wizigmann-Voos, H Schnurch, R Martinez, NP Moller and W Risau. (1993). High affinity VEGF binding and developmental expression suggest $f l k-1$ as a major regulator of vasculogenesis and angiogenesis. Cell 72:835846.

5. Kabrun N, HJ Buhring, K Choi, A Ullrich, W Risau and G Keller. (1997). flk-1 expression defines a unique population of embryonic precursors. Development 124: 2039-2048.

6. Newman PJ. (1997). The Biology of PECAM-1. J Clin Invest 99:3-8.

7. Kallianpur AR, JE Jordan and SJ Brandt. (1994). The SCL/TAL-1 gene is expressed in progenitors of both the hematopoietic and vascular systems during embryogenesis. Blood 83:1200-1208.

8. Anagnostou A, Z Liu, M Steiner, K Chin, ES Lee, N Kessimian and CT Noguchi. (1994). Erythropoietin receptor mRNA expression in human endothelial cells. Proc Natl Acad Sci USA 91:3974-3978.

9. Shalaby F, J Rossant, TP Yamaguchi, M Gertenstein, XF Wu, ML Breitman and AC Schuh. (1995). Failure of bloodisland formation and vasculogenesisin $f l k-1$ deficient mice. Nature 376:62-66.

10. Shalaby F, J Ho, WL Stanford, KD Fischer, AC Schuh, L Schwartz, A Bernstein and J Rossant. (1997). A require- ment for $f l k-l$ in primitive and definitive hematopoiesis and vasculogenesis. Cell 89:981-990.

11. Robb L, I Lyons, R Li, L Hartley, F Kontgen, RP Harvey, D Metcalf and CG Begley. (1995). Absence of yolk sac hematopoiesis from mice with a targeted disruption of the SCL gene. Proc Natl Acad Sci USA 92:7075-7079.

12. Stainier DY, BM Weinstein, HW Detrich 3rd, LI Zon and MC Fishman. (1995). Cloche, an early acting zebrafish gene, is required by both the hematopoietic and endothelial lineages. Development 121:3141-3150.

13. Ferrara N, K Carver-Moore, H Chen, M Dowd, L Lu, KS O'Shea, L Powell-Braxton, KJ Hillan and MW Moore. (1996). Heterozygous embryonic lethality induced by targeted inactivation of the VEGF gene. Nature 380:439-442.

14. Gering M, ARF Rodaway, B Göttgens, RK Patient and AR Green. (1998). The SCL gene specifies haemangioblast development from early mesoderm. EMBO J 17:4029-4045.

15. Eichmann A, C Corbel, V Nataf, P Vaigot, C Breant and NM Le Douarin. (1997). Ligand-dependent development of the endothelial and hemopoietic lineages from embryonic mesodermal cells expressing vascular endothelial growth factor receptor 2. Proc Natl Acad Sci USA 94: 5141-5146.

16. Choi K, M Kennedy, A Kazarov, JC Papadimitriou and G Keller. (1998). A common precursor for hematopoietic and endothelial cells. Development 125:725-732.

17. Nishikawa SI, S Nishikawa, M Hirashima, N Matsuyoshi and H Kodama. (1998). Progressive lineage analysis by cell sorting and culture identifies FLK $1^{+}$VE-Cadherin ${ }^{+}$cells at a diverging point of endothelial and hemopoietic lineages. Development 125:743-752.

18. Risau W, H Sariola, HG Zerwes, J Sasse, P Eklblom, R Kemler and T Doetschmann. (1988). Vasculogenesis and angiogenesis in embryonic stem cell-derived embryoid bodies. Development 102:471-478.

19. Risau W and I Flamme. (1995). Vasculogenesis. Annu Rev Cell Dev Biol 11:73-91.

20. Folkman J and Y Shing. Angiogenesis.(1992). J Biol Chem 267:10931-10934.

21. Folkman J. Clinical applications of research in angiogenesis. (1995). N Engl J Med 333:1757-1763.

22. Asahara T, T Murohara, A Sullivan, M Siver, $R$ van der Zee, T Li, B Witzenbichler, G Schatteman and JM Isner. (1997). Isolation of putative progenitor endothelial cells for angiogenesis. Science 275:964-967.

23. Shi Q, S Rafii, MH Wu, ES Wijelath, C Yu, A Ishida, Y Fujita, S Kothari, R Mohle, LR Sauvage, MA Moore, RF Storb and WP Hammond. (1998). Evidence for circulating bone marrow-derived endothelial cells. Blood 92:362-367.

24. Lin Y, D Weisdorf, A Solovey and RP Hebbel. (1999). Origins of circulating endothelial cells and endothelial outgrowth from blood. J Clin Invest 105:71-77.

25. Gehling UM, S Ergün, U Schumacher, C Wagener, K Pantel, M Otte, G Schuch, P Schafhausen, T Mende, N Kilic, K Kluge, B Schafer, DK Hossfeld and W Fiedler. (2000). In vitro differentiation of endothelial cells from CD133positive progenitors. Blood 95:3106-3112.

26. Peichev M, AJ Naiyer, D Pereira, Z Zhu, WJ Lane, M Williams, MC Oz, DJ Hicklin, L Witte, MA Moore and S Rafii. (2000). Expression of VEGFR-2 and CD133 by cir- 
culating human $\mathrm{CD}^{+} 4^{+}$cells identifies a population of functional endothelial precursors. Blood 95:952-958.

27. Kalka C, H Masuda, T Takahashi, WM Kalka-Moll, M Siver, M Kearney, T Li, JM Isner and T Asahara. (2000). Transplantation of ex vivo expanded endothelial progenitor cells for therapeutic neovascularization Proc Natl Acad Sci USA 28:3422-3427.

28. Murohara T, H Ikeda, J Duan, S Shintani, K Sasaki, H Eguchi, I Onitsuka, K Matsui and T Imaizumi. (2000). Transplanted cord blood-derived endothelial precursor cells augment postnatal neovascularization $\mathrm{J}$ Clin Invest 105:1527-1536.

29. Takahashi T, C Kalka, H Masuda, D Chen, M Silver, M Kearney, M Magner, JM Isner and T Asahara. (1999). Ischemia- and cytokine-induced mobilization of bone marrowderived endothelial progenitor cells for neovascularization Nature Med 5:434-438.

30. Asahara T, T Takahashi, H Masuda, C Kalka, D Chen, H Iwaguro, Y Inai, M Silver and JM Isner. (1999). VEGF contributes to postnatal neovascularization by mobilizing bone-marrow-derived endothelial progenitor cells. EMBO J 18:3964-3972.

31. Gunsilius E, HC Duba, AL Petzer, CM Kahler, K Grunewald, G Stockhammer, C Gabl, S Dirnhofer, J Clausen and G Gastl. (2000). Evidence from a leukemia model for maintenance of vascular endothelium by bonemarrow-derived endothelial cells. Lancet 355:1688-1691.

32. Faloon P, Arentson E, Kazarov A, Deng CX, Porcher C, Orkin S, Choi K. (2000). Basic fibroblast growth factor regulates hematopoietic development. Development 127: 1931-1941.

33. Chung YS, Zhang WJ, Arentson E, Kingsley PD, Palis J, Choi K. (2002). Lineage analysis of the hemangioblast as defined by FLK1 and SCL expression. Development 129: 5511-5520.

34. Grant MB, May WS, Caballero S, Brown GA, Guthrie SM, Mamaes RN, Byrne BJ, Vaught T, Spoerri PE, Peck AB, Scott EW. (2002). Adult hematopoietic stem cells provide functional hemangioblast activity during retinal neovascularization. Nature Med 8:607-612.

35. Pelosi E, M Vatieri, S Coppola, R Botta, M Gabbianelli, V Lulli, G Marziali, B Masella, Muller R, C Sgadari, U Testa, Bonanno and C Peschle. (2002). Identification of the hemangioblast in postnatal life. Blood 100:3203-3208.

36. Kuhlcke K, B Fehse, A Schilz, S Loges, Lindemann C, F Ayuk, F Lehmann, N Stute, NN Fauser, AR Zander and HG Eckert. (2002). Highly efficient retroviral gene transfer based on centrifugation-mediated vector pre-loading of tissue culture vessels. Mol Ther 5:473-478.

37. Ayuk F, Z Li, K Kuhlcke K, C Lindemann, U Schade, HG Eckert, AR Zander and B Fehse. (1999). Establishment of an optimized gene transfer protocol for human primary $\mathrm{T}$ lymphocytes according to clinical requirements. Gene Ther 6:1788-1792.

38. Wahlers A, M Schwieger, Z Li, D Meier-Tackmann, C Lindemann, HG Eckert, D von Laer and C Baum. (2001). Influence of multiplicity of infection and protein stability on expression of retroviral vectors encoding EGFP. Gene Ther 8:477-486.

39. Yin AH, S Miraglia, ED Zanjani, G Almeida-Porada, M
Ogawa, AG Leary, J Olweus, J Kearney and DW Buck. (1997). CD133, a novel marker for human hematopoietic stem and progenitor cells. Blood 90:5002-5012.

40. Miraglia S, W Godfrey, AH Yin, K Atkins, R Warnke, JT Holden, RA Bray, EK Waller and DW Buck. (1997). A novel five-transmembranehematopoietic stem cell antigen: Isolation, characterization, and molecular cloning. Blood 90:5013-5012.

41. De Wynter EA, D Buck D, C Hart, R Heywood, LH Coutinho, A Clayton, JA Rafferty, D Burt, G Guenechea, JA Bueren, D Gagen, LJ Fairbairn, BI Lord and NG Testa. (1998). CD $34^{+} \mathrm{CD} 133^{+}$cells isolated from cord blood are highly enriched in long-term culture initiating cells, NOD/SCID-repopulating cells and dendritic cell progenitors. Stem Cells 16:387-396.

42. Ziegler BL, M Valtieri, GM Porada, R de Maria, R Muller, B Masella, M Gabbianelli, L Casella, E Pelosi, T Bock, ED Zanjani and C Peschle.(1999). KDR receptor: a key marker defining hematopoietic stem cells. Science 285:1553-1558.

43. Raab U, P Lastres, MA Arevalo, JM Lopez-Novoa, C Cabanas, EJ de la Rosa and C Bernabeu. (1999). Endoglin is expressed in the chicken vasculature and is involved in angiogenesis. FEBS Lett 459:249-254.

44. Pierelli L, G Scambia, G Bonanno, S Rutella, P Puggioni, A Battaglia, S Mozetti, M Marone, G Menichella, C Rumi, S Mancuso and G Leone. (2000). CD34 ${ }^{+} \mathrm{CD} 105^{+}$cells are enriched in primitive circulating progenitors residing in the $\mathrm{G} 0$ phase of the cell cycle and contain all bone marrow and cord blood $\mathrm{CD} 34^{+} \mathrm{CD} 39^{\text {low }} / \mathrm{CD} 38^{-}$precursors. Br J Haematol 108:610-620.

45. Cho SK, A Bourdeau, M Letarte and JC Zuniga-Pflucker. (2001). Expression and function of CD105 during the onset of hematopoiesis from $\mathrm{Flk}^{+}$precursors. Blood 2001;98: 3635-3642.

46. Craig W, S Poppema, MT Little, W Dragowska and PM Lansdorp. (1994). CD45 isoform expression on human haematopoietic cells at different stages of development. $\mathrm{Br}$ J Haematol 88:24-30.

47. Terstappen LW, S Huang, M Safford, PM Lansdorp and MR Loken. (1991). Sequential generations of hematopoietic colonies derived from single nonlineage-committed CD34 ${ }^{+}$CD38 ${ }^{-}$progenitor cells. Blood 77:1218-1227.

48. Baum CM, IL Weissmann, AS Tsukamoto, AM Buckle and B Peault. (1992). Isolation of a candidate human hematopoietic stem cell population. Proc Natl Acad Sci USA 89: 2804-2808.

49. Craig W, R Kay, RL Cutler and PM Lansdorp. (1993). Expression of Thy-1 on human hematopoietic progenitorcells. J Exp Med 177:1331-1342.

50. Lee WS, MK Jain, BM Arkonac, G Zhang, SY Shaw, S Kashiki, K Maemura, SL Lee, NK Hollenberg, ME Lee and E Haber. (1998). Thy-1, a novel marker for angiogenesis upregulated by inflammatory cytokines. Circ Res 82:845-851.

51. Danilov SM, VD Gavrilyuk, FE Francke, K Pauls, DW Harshaw, TD McDonald, DJ Miletich and VR Muzykantow. (2001). Lung uptake of antibodies to endothelial antigens: key determinants of vascular immunotargeting. Am J Physiol Lung Cell Mol Physiol 280:L1335-1347.

52. Wright SD. (1995). CD14 and innate recognition of bacteria. J Immunol 55:6-8. 


\section{LOGES ET AL.}

53. Chakravortty D, Y Kato, N Koide, T Sugiyama, M Kawai, M Fukada, T Yoshida and T Yokochi. (1999). Production of tissue factor in CD14-expressing human umbilical vein endothelial cells by lipopolysaccharide. FEMS Microbiol Lett 178:235-239.

54. Jersmann HP, CS Hii, GL Hodge and A Ferrante. (2001). Synthesis and surface expression of CD14 by human endothelial cells. Infect Immun 69:479-485.

55. Fernandez Pujol B, FC Lucibello, UM Gehling, L Lindemann, N Weidner, ML Zuzarte, J Adamkiewicz, HP Elsasser, R Muller and K Havemann. (2000). Endothelial-like cells derived from human CD14 positive monocytes. Differentiation 65:287-300.

56. Boyer M, LE Townsend, LM Vogel, J Falk, D Reitz-Vick, KT Trevor, M Villaba, PJ Bendick and JL Glover. (2000). Isolation of endothelialcells and their progenitor cells from human peripheral blood. J Vasc Surg 31:181-189.

57. Moldovan N, PJ Goldschmidt-Clermont, J Parker-Thornburg, SD Shapiro and PE Kolattukudy. (2000). Contribution of monocytes/macrophages to compensatory neovascularization: the drilling of metalloelastase-positive tunnels in ischemic myocardium. Circ Res 87:378-384.

58. Schmeisser A, CD Garlichs, H Zhang, S Eskafi, C Graffy, J Ludwig, RH Strasser and WG Daniel. (2001). Monocytes coexpress endothelial and macrophagocytic lineage markers and form cord-like structures in Matrigel under angiogenic conditions. Cardiovasc Res 49:671-680.

59. Haylock DN, LB To, TL Dowse, CA Juttner and PJ Simmons. (1992). Ex vivo expansion and maturation of peripheral blood $\mathrm{CD} 34^{+}$cells into the myeloid lineage. Blood 80:1405-1412.

60. Brugger W, W Mocklin, S Heimfeld, RJ Berenson, R Mertelsmann and L Kanz. (1993). Ex vivo expansion of en- riched peripheral blood $\mathrm{CD}^{+} 4^{+}$progenitor cells by stem cell factor, interleukin-1 beta (IL-1 beta), IL-6, IL-3, interferon-gamma, and erythropoietin. Blood 81:2579-2584.

61. Peters SO, EL Kittler, HS Ramshaw and PJ Quesenberry. (1996). Ex vivo expansion of murine marrow cells with Interleukin-1 (IL-1), IL-6, IL-11, and steel factor leads to impaired engraftment in irradiated hosts. Blood 87:30-37.

62. Cairo MS and JE Wagner. (1997). Placental and/or umbilical cord blood: An alternative source of hematopoietic stem cells for transplantation. Blood 90:4665-4678.

63. Gallacher L, B Murdoch, DM Wu, FN Karanu, M Keeney and M Bhatia. (2000). Isolation and characterization of human CD34(-) Lin(-) and CD34(+)Lin(-) hematopoietic stem cells using cell surface markers CD133 and CD7. Blood 95:3113-3120.

64. Choi K. The hemangioblast: A common progenitor of hematopoietic and endothelial cells. J Hematother Stem Cell Res 11:91-101.

Address reprint requests to: Dr. Ursula M. Gehling University Hospital Hamburg-Eppendorf Department of Medicine Division of Hematology/Oncology Martinistrasse 52 20246 Hamburg, Germany E-mail: gehling@uke.uni-hamburg.de

Received December 15, 2003; accepted December 31, 2003. 